\title{
Current Awareness
}

\section{Compiled by Katherine Read and Laura Griffiths at the Institute of Advanced Legal Studies}

This Current Awareness column, and previous Current Awareness columns, are fully searchable in the caLIM database (Current Awareness for Legal Information Managers). The caLIM database is available on the Institute of Advanced Legal Studies website at: http://ials.sas.ac.uk/ library/caware/caware.htm

The 'Cardiff Index to Legal Abbreviations' is available at http://www.legalabbrevs.cardiff.ac.uk/

\section{BREXIT}

Gordon Anthony 'Brexit and the Common Law Constitution' (2018) 24 EPL 672

Conor Crummey and Eugenio Velasco Ibarra 'Statutory Conventions: Conceptual Confusion or Sound Constitutional Development?' [2018] October P.L. 613

Mark Elliott and Stephen Tierney 'Political Pragmatism and Constitutional Principle: The European Union (Withdrawal) Act 2018' [2019] January P.L. 37

Ryan Esparza 'En Vogue: The Risks of Brexit to the European Fashion Industry' (2018) 46 Intl. J. Legal Info. 163

Asif Hameed 'The Rule of Recognition and Sources of Law in Miller' [2019] January P.L. 61

Menelaos Markakis 'Brexit and the EU Charter of Fundamental Rights' [2019] January P.L. 82

Stephanie Pywell 'Something Old, Something New: Busting Some Myths About Statutory Instruments and Brexit' [2019] January P.L. 102

Charalambos Tsilotis 'The Irrational Brexit and the Revocability of the Withdrawal Notification of the United Kingdom to the European Council' (2018) 24 EPL 659

Michael Zander 'Brexit: the Endgame' (2018) 168 (78I2) NLJ 10

\section{COPYRIGHT}

Enrico Bonadio and Nicola Lucchi (eds), Non-Conventional Copyright: Do New and Atypical Works Deserve Protection? (Edward Elgar 2018)
Andrés Guadamuz 'Copyright and the Blockchain' (2018) Sept/ Oct I.N.L I

Jingze Li 'Intellectual Property Licensing Tensions: Utilising Open Source Software in the Formal Standard-Setting Context' (2018) 9(2) EJLT http://ejlt.org/article/view/593 Accessed $3^{\text {rd }}$ January 2019

Jane Secker and Chris Morrison 'Copyright Literacy: Beyond Compliance' (2018) Nov/Dec Information Professional 22

J.A.L. Sterling, World Copyright Law (5 $5^{\text {th }}$ edn, Sweet and Maxwell 2018)

Hannibal Travis, Copyright and Class Struggle: The Ownership of Ideas in the Social Media Age (Cambridge University Press 2018)

\section{EUROPEAN UNION}

Verena von Bomhard and Alexander von Muhlendahl, Concise European Trade Mark Law ( $3^{\text {rd }}$ edn, Kluwer Law International 2018)

Petra Láncos 'A Hard Core Under the Soft Shell: How Binding is Union Soft Law for Member States?' (2018) 24 EPL 755

Valsamis Mitsilegas, EU Criminal Law after Lisbon (Hart Publishing 20I8)

Jacob Öberg 'National Parliaments and Political Control of EU Competences: A Sufficient Safeguard of Federalism?' (2018) 24 EPL 695

P.L. Parcu, G. Monti and M. Botta, Private Enforcement of EU Competition Law: The Impact of the Damages Directive (Edward Elgar Publishing 2018)

Steen Treumer and Mario Comba (eds), Modernising Public Procurement: The Approach of EU Member States (Edward Elgar 2018)

Sybe de Vries, Henri de Waele and Marie-Pierre Granger (eds) Civil Rights and EU Citizenship: Challenges at the Crossroads of the European, National and Private Spheres (Edward Elgar 2018) 


\section{INFORMATION POLICY}

Khurshid Ahmad (ed), Social Computing and the Law: Uses and Abuses in Exceptional Circumstances (Cambridge University Press 2018)

Hala Bou Alwan 'Policy Development and Frameworks for Cyber Security in Corporates and Law Firms' (2018) 46 Intl. J. Legal Info. 137

Nick Holmes ‘Open Data: Free to Use and Republish' (2018) Sept/Oct I.N.L 7

Chris Marsden 'The Regulated End of Internet Law, and the Return to Computer and Information Law?' (20I8) 34 CLSR 15

Eugenia Politou and others 'Backups and the Right to be Forgotten in the GDPR: An Uneasy Relationship. (2018) 34 CLSR I 247

Yves Poullet 'Is the General Data Protection Regulation the Solution'? (2018) 34 CLSR 773

Eduardo Ustaran 'GDPR- the Dust is Settling' (2018) Nov/Dec I.N.L I

Helen Wong, Cyber Security: Law and Guidance (Bloomsbury Professional 2018)

\section{INFORMATION TECHNOLOGY}

Paul McMahon 'Legal Information Online in the Republic of Ireland' (20I8) Nov/Dec I.N.L 8

Barry Vickery 'We've Always done it this Way' (2018) I8 LIM 215

Barry Vickery 'InfoTrack: the Rise and Rise of Distraction' (2018) I8 LIM 239

\section{INTERNATIONAL LAW}

Farid Ahmadov, The Right of Actio Popularis before International Courts and Tribunals (Brill Nijhoff 2018)

Pavel Bureš 'Human Dignity: an Illusory Limit for the Evolutive Interpretation of the ECHR' (2017) II0 Amicus Curiae 20

Shaheed Fatima, Protecting Children and Armed Conflict (Hart Publishing 2018)

Lloyd Freeburn, Regulating International Sport: Power, Authority and Legitimacy (Brill Nijhoff 2018)

John Heieck, A Duty to Prevent Genocide: Due Diligence Obligations Among the P5 (Edward Elgar Publishing 2018)

S. Jayakumar (and others) (eds), The South China Sea Arbitration: The Legal Dimension (Edward Elgar 2018)
Karim Khan and Rodney Dixon, Archbold International Criminal Courts: Practice, Procedure and Evidence $\left(5^{\text {th }}\right.$ edn, Sweet and Maxwell 2018)

Marcelo G. Kohen and Mamadou Hebie (eds), Research Handbook on Territorial Disputes in International Law (Edward Elgar 2018)

Stephen Minas, Jordan Diamond and Holly Doremus (eds), Stress Testing the Law of the Sea: Dispute Resolution, Disasters and Emerging Challenges (Brill Nijhoff 2018)

Caroline Osborne 'International Investment Law and Alternative Dispute Resolution: A Guide to Web Based Resources' (2018) 46 Intl. J. Legal Info. I8I

Will Smiley, From Slaves to Prisoners of War: The Ottoman Empire, Russia, and the Making of International Law (Oxford University Press 2018)

Amy Strecker, Landscape Protection in International Law (Oxford University Press 2018)

Geraldine Van Bueren 'A Justiciable Right to Food - A Possibility for the United Kingdom?' [2019] January P.L. 146

\section{JUDICIARY}

Julian Acratopulo 'Uneasy Lies the Head that Wears the Crown' (2018) I68 (78I8) NLJ 21

Erin F. Delaney and Rosalind Dixon (eds), Comparative Judicial Review (Edward Elgar Publishing 2018)

Susan deMaine 'Access to the Justices' Papers: A Better Balance' (2018) II0 Law Libr. J. 185

John Nicholson 'Extraordinary Working Lives' (2018) November Counsel: The Journal of the Bar of England and Wales 24

Michael Reznik 'Financial Services Tribunal: the Seal of Political Approval' (2018) I68 (78I5) NLJ 9

John Tanburn 'Mending the Net' (2018) 168 (78I8) NLJ 17

Graham Zellick 'QC or not QC? A Judicial Conundrum' (2018) $168(7818) \mathrm{NLJ} 19$

\section{LAW LIBRARIANS}

Shamika Dalton, Gail Mathapo and Endia Sowers Paige 'Navigating Law Librarianship While Black: A week in the Life of a Black Female Law Librarian' (2017) I I0 Law Libr. J. 429

Marisa Dellaca 'Leading Libraries in a VUCA World' (2018) 26 ALL 134 
Kirsty McPhee 'Law Librarians and "Legal Work": the Regulatory Grey Area Preventing a Greater Contribution" (2018) 26 ALL 159

\section{LAW LIBRARIES}

Harriet Dapo-Asaju and Oludayo Bamgbose 'Relocation of Law Libraries in an African University: The Ajayi Crowther University's Experience' (2018) 26 ALL 140

Marisa Dellaca 'Leading Libraries in a VUCA World' (2018) 26 ALL 134

Karen Latimer '2050: a Library Space Odyssey. Planning a Future Library' (2018) I8 LIM 203

Liz Murray and Claudia Holland 'Interview with the New Head of the Library of the Max Planck Institute for Comparative and International Private Law' (20I8) I8 LIM 246

Margaret Watson 'All Change at the Bodleian Law Library' (2018) Nov/Dec Information Professional 32

\section{LAW LIBRARY ADMINISTRATION}

Brian Detweiler, Kimberley Mattioli and Mike Martinez 'Reaching and Teaching Millennials: Designing the Future of Student Services' (2018) I8 LIM 219

Claire Fox '(Business) Planning For the Future' (2018) I8 LIM 233

Timonie Green and Diane Miller 'The Library in an Agile World: Case Studies From Gowling WLG and Withers LLP' (2018) I8 LIM 209

Gemma John 'Libraries at Work: Exploring the Relationship Between Libraries at Work' (2018) I8 LIM 194

\section{LAW REPORTS}

Michael Eshleman 'A History of the Digests' (2018) II 0 Law Libr. J. 235

Daniel Hoadley 'Open Access to Case Law - How do We Get There?' (2018) Nov/Dec 20I8 I.N.L 3

\section{LEGAL BIOGRAPHY}

George H. Gadbois, Judges of the Supreme Court of India 195089 (Oxford University Press 2018)

\section{LEGAL CITATIONS}

Susan Barker 'Exploring the Development of a Standard System of Citation Metrics for Legal Academics' (2018) 43 (2)

Canadian Law Library Review 10
Jamie Rasmussen 'Horseless Carriages with Buggy-Whip Holders: the Failure of Legal Citation Reform in the 1990's.' (2018) II0 Law Libr. J. 22।

\section{LEGAL EDUCATION}

Michael Draper, Simon Gibbon and Jane Thomas 'Lecture Recording: A New Norm' (2018) 52 Law Teacher 316

Jessica Guth and Tamara Hervey 'Threats to Internationalised Legal Education in the Twenty-First Century UK' (2018) 52 Law Teacher 350

Svetlana Kochkina 'Teaching Legal Research and Government/ Legal Information: Yes, We do it, but how?' (2018) 43 (2) Canadian Law Library Review 9

Lindon Thomas (and others) (eds), Reimagining Clinical Legal Education (Hart Publishing 2018)

Chloë Wallace 'The Pedagogy of Legal Reasoning: Democracy, Discourse and Community' (2018) 52 Law Teacher 26I

J. Clare Wilson and Caroline Stevens 'Perceptions of Psychological Well-Being in UK Law Academics' (2018) 52 Law Teacher 335

\section{LEGAL PROFESSION}

Katie Cuyler 'Competitive Analysis in Corporate Law Firms: STEEP* Analysis' (2018) 43 (2) Canadian Law Library Review 18

Freda Grealy 'Experiential Training for Real-Life Professional Impact: the Formation of Professional Identity in Trainee Solicitors Through a Discrete Intervention Course on Ethics and Lawyering Skills' (2018) 52 Law Teacher 295

Ann Hemming and James Wilkinson 'The Legal Career: (R)Evolution and Mentoring through Technology' (2018) I8 LIM 227

Rob Mackinlay 'Maximum Innovation, Minimum Disruption' (2018) October Information Professional 22

Christine Parker and Adrian Evans, Inside Lawyers' Ethics ( $3^{\text {rd }}$ edn, Cambridge University Press 2018)

\section{LEGAL SYSTEMS}

William E. Butler, Russian Law and Legal Institutions $\left(2^{\text {nd }}\right.$ edn, Wildy, Simmonds and Hill Publishing 2018)

Stephen Chan, A Practical Guide to Partnership Law in Scotland (W.Green 2018)

Albert H. Y. Chen and Andrew Harding (eds), Constitutional Courts in Asia: A Comparative Perspective (Cambridge University Press 2018) 
Fraser Davidson (and others), Commercial Law in Scotland (5 edn, W.Green 2018)

Anver M. Emon and Rumee Ahmed (eds), The Oxford Handbook of Islamic Law (Oxford University Press 2018)

Alison Foster 'Electoral Law. Unfit for the $21^{\text {st }}$ Century?' (20I8) November Counsel: The Journal of the Bar of England and Wales 28

Lucas Gomes 'The Influences of Common Law on the Brazilian New Code of Civil Procedure' (2018) 46 Intl. J. Legal Info. 176

Tom Guthrie, Social Work Law in Scotland $\left(4^{\text {th }}\right.$ edn, Bloomsbury Professional 2018)

Thomas Muinzer 'Is the Climate Change Act 2008 a Constitutional Statute?' (2018) 24 EPL 733

Amanda Reid, Kenneth L. Port and Shine Tu, Fundamentals of United States Intellectual Property Law: Copyright, Patent and Trademark ( $6^{\text {th }}$ edn, Kluwer Law International 20I8)

Philip Sales 'Legalism in Constitutional Law: Judging in a Democracy' [2018] October P.L. 687

Gideon Sapir, The Israeli Constitution: From Evolution to Revolution (Oxford University Press 2018)
Stephen Thomson, Administrative Law in Hong Kong (Cambridge University Press 2018)

Joe Tomlinson 'Crowdfunding Public Interest Judicial Reviews: A Risky New Resource and the Case for a Practical Ethics' [2019] January P.L. 166

Helene Tyrrell, Human Rights in the UK and the Influence of Foreign Jurisprudence (Hart Publishing 2018)

\section{PUBLISHING}

Paul Maharg, Abhilash Nair and Catherine Easton 'The Most Audacious and Specific Plan for Knowledge, Freedom and a Better World': Developing Radical Pathways to Free Open Journals' (2018) 9(I) EJLT http://ejlt.org/article/view/ 630 Accessed $13^{\text {th }}$ November 2018

Kees (C.) van Noortwijk 'Assessing the Impact of Legal Publications Building a Citations Index Using Automatic Reference Analysis' (2018) 9(2) EJLT http://ejlt.org/article/ view/452 Accessed $3^{\text {rd }}$ January 2019

\section{TREATIES}

Michael J. Bowman and Dino Kritsiotis (eds), Conceptual and Contextual Perspectives on the Modern Law of Treaties (Cambridge University Press 2018) 